\title{
The First Genetic Linkages among Expressed Regions of the Garlic Genome
}

\author{
Yayeh Zewdie \\ Department of Biology, California State University, Fresno, CA 93740 \\ Michael J. Havey \\ Agricultural Research Service, U.S. Department of Agriculture, Vegetable Crops Unit, Dept. of \\ Horticulture, University of Wisconsin, Madison, WI 53706
}

James P. Prince

Department of Biology, California State University, Fresno, CA 93740

\author{
Maria M. Jenderek ${ }^{1}$ \\ Agricultural Research Service, U.S. Department of Agriculture, National Arid Land Plant Genetic \\ Resource Unit, Parlier, CA 93648
}

\begin{abstract}
AdDITIONAL INDEX wORDS. Allium sativum, genetic mapping, male fertility, RAPD, SNP, SSR
Abstract. Garlic (Allium sativum L.) has been cultivated by asexual propagation since time immemorial. The discovery of male-fertile garlic accessions has opened a venue for genetic studies and improvement through sexual recombination. $\mathrm{An} \mathrm{S}_{1}$ family of 84 plants was generated from a single male-fertile heterozygous plant from the U.S. Dept. of Agriculture Plant Introduction 540316 and used to identify the first genetic linkages in garlic based on single nucleotide polymorphisms, simple sequence repeats, and randomly amplified polymorphic DNAs. Thirty-seven markers formed nine linkage groups covering 415 centimorgans $(\mathrm{cM})$ with average distance of $15 \mathrm{cM}$ between loci; other 16 loci remained unlinked. A male fertility locus was placed on the map. This first genetic map of garlic is a seminal step toward the genetic improvement of garlic and eventual marker-assisted breeding.
\end{abstract}

Garlic is an asexually propagated plant cultivated since time immemorial (Simon, 2004). The center of origin for garlic is central Asia, from which the plant spread worldwide and is now cultivated from mountainous tropical to temperate regions (Etoh and Simon, 2002). The bulb is the most economically important part of the garlic plant; however, its fresh leaves, pseudostems, and bulbils are also consumed by humans (Fritsch and Friesen, 2002). Although garlic is primarily consumed for its flavor, it has well-defined medicinal benefits (Augusti, 1990; Block et al., 1984; Makheja and Bailey, 1990). The organosulfur compounds accumulated by garlic show significant antibacterial, antifungal, anticarcinogenic, antiasthmatic, and antidiabetic properties, as well as lipid-lowering ability through inhibition of cholesterol biosynthesis (Keusgen, 2002).

Commercial production of garlic is exclusively by asexual propagation. Sterility in garlic has been attributed to both genetic and environmental factors, including irregular chromosome pairing, chromosomal deletion, anther degeneration, and competition for nutrients between topsets and flowers (Etoh and Simon, 2002). Because of asexual propagation, garlic improvement has been limited to clonal selection of spontaneous mutants or sports

Received for publication 28 Sept. 2004. Accepted for publication 4 Dec. 2004. The nested primers used in this study were designed by Drs. Joseph Kuhl (Michigan State Univ.) and William Martin (USDA and Univ. of Wisconsin). We thank Drs. John McCallum (Crop and Food Research, Lincoln, New Zealand) and Jernej Jakse (Univ. of Wisconsin) for SSR primer sequences. We also thank Linda Donnelly (California State Univ., Fresno) for her technical assistance. Names are necessary to report factually on available data; however, the U.S. Dept. of Agriculture (USDA) neither guarantees nor warrants the standard of the product, and the use of the name by USDA implies no approval of the product to the exclusion of others that may also be suitable. This work was supported by U.S. Dept. of Agriculture, Initiative for Future Agriculture and Food Systems Grant 2001-04434.

${ }^{1}$ To whom requests for reprints should be addressed. E-mail address: mjenderek@fresno.ars.usda.gov with desirable horticultural traits, such as bulb color, numbers of cloves per bulb, or the nonflowering phenotype (Lampasona et al., 2003). It was believed that lack of sexual reproduction would lead to restricted morphological and genetic variation in garlic (Fritsch and Friesen, 2002); however, a number of researchers have reported diversity for morphological characteristics and molecular markers among garlic accessions (Ipek et al., 2003; Lampasona et al., 2003). The discovery of male-fertile garlic accessions in Central Asia (Etoh, 1983, 1986) stimulated research on sexual reproduction (Jenderek, 1998; Kik, 2002). Nevertheless, garlic genetics is at a very rudimentary stage. Garlic is a diploid $(2 \mathrm{n}=2 \mathrm{x}=16)$ plant with one of the largest genomes (1.59 $\times 10^{10}$ basepairs) among all cultivated plants (Ori et al., 1998). There are few reports on molecular markers in garlic. Amplified fragment length polymorphisms (AFLP), randomly amplified polymorphic DNA (RAPD), and isozyme markers have been used to study genetic diversity among garlic clones (Ipek et al., 2003; Lampasona et al., 2003; Volk et al., 2004). Etoh and Hong (2001) reported phenotypic association of two RAPD markers with male fertility in garlic. Other advances in garlic genetics included the development of a low-coverage bacterial artificial chromosome (BAC) library of garlic useful for molecular cytogenetics (Lee et al., 2003) and a stable transformation of garlic by particle bombardment (Sawahel, 2002).

Genetic linkage maps are powerful tools for localization of genes, understanding the genetic bases of complex traits, markerassisted breeding, and map-based cloning of important genes (Hu et al., 2004; Sardesai et al., 2002; Zhang et al., 2001). The development of a genetic linkage map will enhance garlic improvement by allowing marker-assisted selection and identification of genes that control economically important traits. The objectives of this research were to develop the first genetic linkage map of garlic and to clarify the genetic basis of male fertility. 


\section{Materials and Methods}

Plant material and population development. A family of $84 \mathrm{~S}_{1}$ plants was produced by self-pollination of clones from a single garlic plant of PI 540316, an accession maintained by the U.S. Dept. of Agriculture (USDA), Agricultural Research Service, Western Regional Plant Introduction Station, Pullman, Wash. The accession originated from the former Soviet Union. PI 540316 was selected from other male fertile garlic accessions, because it produced the highest number of $S_{1}$ seeds and had the highest number of $S_{1}$ plants established in a field (Jenderek, 2004). The parental plant produced over 200 flowers per umbel, with purple petals and anthers with readily shedding pollen grains.

Cloves from the parental line, PI 540316, were planted at the beginning of October 2000 in the field at USDA, National Arid Land Plant Genetic Resource Unit in Parlier, Calif. Bulbils present in inflorescences were manually removed at flower bud stage and the plants were caged at flowering in insect-proof net. Flies (Protophorma terranaenvae Robineau-Deavoidy) were added to aid in pollination and $\mathrm{S}_{1}$ seeds were harvested in Aug. 2001 (Jenderek, 2004).

In the 2001-02 growing season, seeds were germinated in vitro under aseptic conditions on a Murashige and Skoog growth media (M-5524; Sigma-Aldrich Co., St. Louis) and at two to three leaf stage the seedlings were transferred to plastic pots $(7 \times 7 \times$ $7 \mathrm{~cm}$ ) containing an artificial medium soil mix (Sunshine Mix No. 4; Sun Gro Horticulture Canada Ltd., Vancouver, Canada) in screenhouse. When the seedlings attained three to four leaf stages, in Feb. 2002, they were transplanted to the field at $5 \mathrm{~cm}$ spacing. Standard practices for growing garlic in California were used (Mann and Little, 1957). At flowering stage, male fertility was scored based on pollen viability (Jenderek and Hannan, 2004). Plants with no viable pollen were considered as male-sterile whereas plants with one or more viable pollen were considered as male-fertile. Bulbs were harvested in Aug. 2002.

At the end of Oct. 2002, cloves from each $S_{1}$ progeny plant were planted in the field and at the flowering stage, randomly selected four plants from each $S_{1}$ progeny were scored again for male fertility. Bulbs were harvested at the end of July 2003. Similar to the previous season, in the 2003-04 growing season, cloves from each $S_{1}$ progeny plant were planted and male fertility was scored for the third time.

DNA EXTRACTION, PRIMERS, PCR CONDITION, AND SEQUENCING. At the six to eight leaf stage in the 2001-02 growing season, fresh leaf samples were taken from the penultimate leaf of the parental plant and each $\mathrm{S}_{1}$ plant. Tissues were stored at $-80{ }^{\circ} \mathrm{C}$ until DNA was extracted. Two to three grams of leaf tissue from each sample was used to extract DNA following the procedures as described by Kuhl et al. (2001). A total of 302 nested primers were designed as previously described (Kuhl et al., 2004) from 278 onion (Allium cepa L.) ESTs (Kuhl et al., 2004) and 24 cDNAs previously mapped in onion (King et al., 1998). Nested primer sets were used to amplify genomic regions from garlic using DNA from the parental plant, PI 540316. The complete list of primers and their sequences are available from the authors. Each PCR reaction contained $30 \mathrm{ng}$ of garlic genomic DNA, $0.25 \mathrm{~mm} \mathrm{dNTPs,}$ 0.45 unit of Takara Ex Taq (Takara Shuzo Co., Otsu, Japan), 1X reaction buffer provided by the manufacturer (Takara), and 0.5 $\mu \mathrm{M}$ of each forward and reverse primers in a $20-\mu \mathrm{L}$ volume. Initial PCR with external primers was run at $94^{\circ} \mathrm{C}$ for 2 min, 25 cycles of $95^{\circ} \mathrm{C}$ for $30 \mathrm{~s}, 55^{\circ} \mathrm{C}$ for $1 \mathrm{~min}$, and $72{ }^{\circ} \mathrm{C}$ for $1 \mathrm{~min}$ with a final extension at $72{ }^{\circ} \mathrm{C}$ for $10 \mathrm{~min}$. For the nested PCR, $1 \mu \mathrm{L}$ of a 1:20 dilution of the initial PCR reaction was used as template. The PCR conditions were the same as the external PCR except that the annealing temperatures were optimized using a gradient PCR machine to produce single amplicons, which were excised from agarose gels, purified using the QIAquick gel extraction kit (QIAGEN, Valencia, Calif.), and TA cloned into the pGEM-T Easy vector (Promega Corp., Madison, Wis.). Five white colonies from each cloning reaction were randomly selected and transferred to liquid LB media with ampicillin for overnight growth. Plasmid DNAs were extracted using the QIAprep Spin miniprep kit (QIAGEN). Insert sizes were confirmed by EcoRI digestion and agarose-gel (1.5\%) electrophoresis. Sequencing of inserts was performed after $\mathrm{T} 7$ priming using the BigDye Terminator Cycle Sequencing Kit [Applied Biosystems (ABI), Foster City, Calif.]. Alignment and editing of sequences from each amplicon, as well as identification of single nucleotide polymorphisms (SNP) and insertion-deletions (indel) events, were completed using the Sequencher software version 4.1 (Gene Codes Corp., Ann Arbor, Mich.) and ClustalW (Thompson et al., 1994).

Primers amplifying polymorphic fragments from the parental DNA were used to screen the $S_{1}$ plants. Eight microliters of the nested-PCR amplicons from each of the segregating plants were analyzed on agarose gels to insure that single fragments were present. The remaining volume from the PCR reactions was purified for direct sequencing using a presequencing kit [United States Biochemical (USB), Cleveland] according to the manufacturer's protocol. Clark (1990) reported that sequencing of PCR products of a heterozygous plant reveals both alleles. SNPs and indels among the segregating individuals were identified after sequence alignment with the parental amplicon and analyzed using Sequencher and ClustalW. Some nested primers did not amplify products from some progenies and the presence vs. absence of amplicons over replicated PCR reactions was scored as dominant characters.

Thirty-eight primers were designed from onion ESTs that carry putative simple sequence repeats (SSR) as described by Kuhl et al. (2004). The forward primers were fluorescently labelled with FAM. PCR reactions contained $25 \mathrm{ng}$ of genomic DNA, $0.2 \mathrm{~mm}$ dNTPs, 0.375 unit of Ex Taq, 1X of the manufacturer's buffer, and $0.5 \mu \mathrm{M}$ of each forward and reverse primer in a $15 \mu \mathrm{L}$ reaction volume. Amplification was performed with initial denaturing at $95{ }^{\circ} \mathrm{C}$ for $5 \mathrm{~min} ; 26$ cycles of $94^{\circ} \mathrm{C}$ for $20 \mathrm{~s}, 60{ }^{\circ} \mathrm{C}$ for $40 \mathrm{~s}$, and $72{ }^{\circ} \mathrm{C}$ for $80 \mathrm{~s}$, with a final extension at $72{ }^{\circ} \mathrm{C}$ for $7 \mathrm{~min}$. The DNA fragments were separated using ABI 3700 and analyzed using Genotyper Ver. 3.7NT (ABI).

Twenty-seven decamer Operon primers (Operon Biotechnologies, Alameda, Calif.) were used to screen six randomly selected $\mathrm{S}_{1}$ progeny plants. Primers that revealed polymorphisms among this subset of plants were used to screen all $\mathrm{S}_{1}$ plants. PCR reactions contained $50 \mathrm{ng}$ of genomic DNA, 0.2 mM dNTPs, 0.56 unit Ex Taq, $1 \mathrm{X}$ of the manufacturer's buffer, and $0.48 \mathrm{pm}$ of the primer in a final volume of $25 \mu \mathrm{L}$. Cycling conditions were $94^{\circ} \mathrm{C}$ for 2 min, followed by 40 cycles of $94^{\circ} \mathrm{C}$ for $30 \mathrm{~s}, 45^{\circ} \mathrm{C}$ for $45 \mathrm{~s}$, and $72{ }^{\circ} \mathrm{C}$ for $1 \mathrm{~min}$ with a final extension at $72{ }^{\circ} \mathrm{C}$ for $10 \mathrm{~min}$.

Data ANALYsis. Segregation of markers was tested for goodnessof-fit to 1:2:1 and 3:1 ratios using chi-square analyses. Linkages were detected using Mapmaker /EXP version 3 (Lander et al., 1987, 1992) at logarithm of the odd's (LOD) 5 and maximum distance of $30 \mathrm{cM}$. Map distances in centimorgans were calculated using the Kosambi mapping function (Kosambi, 1943). 


\section{Results}

DEVELOPMENT OF THE SEGREGATING FAMILY. We developed the first publicly available segregating family of garlic by self-pollination of a single plant from PI 540316. Because garlic has been asexually propagated for millennia, we expected and observed lethality and poor vigor among the $S_{1}$ plants; only $57 \%$ of sown seeds produced plants. None of the $S_{1}$ plants were identical to the parental plant for the segregating polymorphisms, indicating that they were sexually derived and not from an apomictic event.

Continuous phenotypic variation was observed among $S_{1}$ plants for flower-stalk height, number of flowers per umbel, bulb weight, and number of cloves per bulb (data not presented). Male fertility segregated as 52 fertile to 32 sterile among the $S_{1}$ plants. Although this segregation deviated significantly from a single-gene model $(P=0.006)$, the discrete segregation for male fertility vs. sterility and the dominance of male fertility in PI 540316 supported a genetic locus (Mf) conditioning male fertility in garlic.

MoleCUlar markers. We designed nested PCR primers and selected those that amplified single fragments from the parental plant DNA. We sequenced at least five amplicons for each primer set to reveal SNPs and indels in the parental plant. Sequencing of amplicons from the parental DNA revealed 83 SNPs and eight indels. Among the $\mathrm{S}_{1}$ plants, 30 SNPs, 18 amplicons scored as presence vs. absence, one indel, one SSR, and two RAPDs segregated (Tables 1 and 2). SNPs and indels that were polymorphic in the parental DNA, but did not segregate among progenies, may be polymorphisms among duplicated regions of the garlic genome. Among the segregating SNPs, $63 \%$ were transitions $(26 \% \mathrm{~T} / \mathrm{C}$ and $37 \% \mathrm{~A} / \mathrm{G})$ and $37 \%$ were transversions $(11 \% \mathrm{~A} / \mathrm{T}, 11 \% \mathrm{G} / \mathrm{C}, 9 \% \mathrm{~A} / \mathrm{C}$, and $6 \% \mathrm{G} / \mathrm{T})$. Across all amplicons that carried segregating SNPs, garlic had one SNPfor every 210 basepairs (Table 1). Many of the molecular markers showed significant segregation distortion (Table 2). For the SNPs, segregation distortion favored one homozygote. For markers scored as the presence vs. absence of amplicons, segregations were skewed toward the presence of an amplicon.

Garlic LinKage analyses. Linkage analysis of 52 molecular markers and the male fertility $(M f)$ locus produced nine linkage groups (LG) covering a total of $414.5 \mathrm{cM}$ with the average distance of $14.8 \mathrm{cM}$ between markers (Fig. 1). The linkage groups varied in length from $118.1 \mathrm{cM}$ (eight markers in LG-A) to 4.9 (two markers in LG-I). Sixteen markers were unlinked (ACAAC24_PA, ACACU91_PA, ACADQ29, ACADR76_PA, ACADS09_PA, ACAEI52_PA, ACABC10, ACAAL62+ACADZ01, API18, API47, ACAEI72_PA, ACABI04_PA, ACABO23F+ACABO23R_PA, ACAET81_PA, ACAFP01, and ACAHH57+ACAGD43_PA). The $M f$ locus was loosely linked to the SSR ACM91 and SNP ACAGW96 on linkage group E. (1998).
Table 1. Locus names, amplicon lengths, and frequencies and types of single nucleotide poly-

\begin{tabular}{|c|c|c|c|}
\hline Locus name ${ }^{z}$ & $\begin{array}{l}\text { Amplicon } \\
\text { length (bp) }\end{array}$ & $\begin{array}{c}\text { No. of } \\
\text { SNPs/amplicon }\end{array}$ & Type of SNP \\
\hline$\overline{\mathrm{ACAAJ} 79}$ & 590 & 3 & $\mathrm{~T} / \mathrm{C}, \mathrm{A} / \mathrm{T}$ \\
\hline ACABP69 & 311 & 1 & $\mathrm{~A} / \mathrm{T}$ \\
\hline ACACF11 & 226 & 1 & $\mathrm{G} / \mathrm{C}$ \\
\hline ACACU91 & 404 & 1 & $\mathrm{~T} / \mathrm{C}$ \\
\hline ACADF77 & 237 & 2 & $\mathrm{G} / \mathrm{A}$ \\
\hline ACADQ29 & 219 & 1 & $\mathrm{~T} / \mathrm{C}$ \\
\hline ACAEI52 & 536 & 2 & G/A \\
\hline ACAEL31 & 413 & 2 & $\mathrm{G} / \mathrm{A}$ \\
\hline ACAGG12 & 272 & 3 & $\mathrm{~A} / \mathrm{C}, \mathrm{T} / \mathrm{C}, \mathrm{G} / \mathrm{C}$ \\
\hline AJK295 & 235 & 1 & $\mathrm{G} / \mathrm{C}$ \\
\hline AOB155 & 330 & 1 & $\mathrm{G} / \mathrm{C}$ \\
\hline AOB271 & 330 & 1 & $\mathrm{G} / \mathrm{C}$ \\
\hline ACABC 10 & 816 & 1 & $\mathrm{~T} / \mathrm{C}$ \\
\hline ACAGV59 & 680 & 1 & $\mathrm{G} / \mathrm{T}$ \\
\hline ACAAL62+ACADZ01 & 548 & 4 & $\mathrm{~A} / \mathrm{T}, \mathrm{T} / \mathrm{C}, \mathrm{A} / \mathrm{C}, \mathrm{G} / \mathrm{A}$ \\
\hline API15 & 330 & 1 & $\mathrm{G} / \mathrm{A}$ \\
\hline API18 & 1300 & 2 & $\mathrm{~T} / \mathrm{C}, \mathrm{G} / \mathrm{A}$ \\
\hline API31 & 302 & 1 & $\mathrm{~A} / \mathrm{C}$ \\
\hline API47 & 1400 & 3 & $\mathrm{G} / \mathrm{A}$ \\
\hline API66 & 609 & 1 & $\mathrm{G} / \mathrm{A}$ \\
\hline ACAEI72 & 232 & 1 & $\mathrm{~T} / \mathrm{C}$ \\
\hline ACAFV90 & 257 & 2 & $\mathrm{~T} / \mathrm{C}$ \\
\hline ACADS93 & 710 & 9 & $\mathrm{G} / \mathrm{A}, \mathrm{G} / \mathrm{C}, \mathrm{A} / \mathrm{T}, \mathrm{T} / \mathrm{C}, \mathrm{A} / \mathrm{C}$ \\
\hline ACACS33 & 332 & 3 & $\mathrm{G} / \mathrm{A}, \mathrm{T} / \mathrm{C}, \mathrm{G} / \mathrm{A}$ \\
\hline ACAGW96 & 470 & 4 & $\mathrm{~T} / \mathrm{C}, \mathrm{G} / \mathrm{T}$ \\
\hline ACAAB50 & 314 & 4 & $\mathrm{G} / \mathrm{A}, \mathrm{A} / \mathrm{T}, \mathrm{T} / \mathrm{G}$ \\
\hline ACAFP01 & 477 & 1 & $\mathrm{G} / \mathrm{A}$ \\
\hline ACABZ07 & 288 & 3 & $\mathrm{G} / \mathrm{C}, \mathrm{A} / \mathrm{C}, \mathrm{G} / \mathrm{A}$ \\
\hline ACAAR73 & 196 & 4 & $\mathrm{~A} / \mathrm{C}, \mathrm{T} / \mathrm{C}, \mathrm{G} / \mathrm{A}, \mathrm{G} / \mathrm{T}$ \\
\hline ACABE16 & 332 & 1 & $\mathrm{~A} / \mathrm{T}$ \\
\hline Totals & 13,696 & 65 & \\
\hline $\mathrm{bp} / \mathrm{SNP}$ & 210.7 & & \\
\hline
\end{tabular}

$\overline{{ }^{2} \text { Name of the locus was after their respective primers name and corresponds to onion expressed }}$ (AC prefixes) or simple sequence repeats (ACM91) as described by Kuhl et al. (2004) or previously mapped cDNAs (AOB or API prefixes) as described by King et al.

Discussion

The discovery of male-fertile garlic has allowed for production of sexual progeny plants and opened the door for genetic improvement of this important vegetable (Simon and Jenderek, 2003). We developed the first, in the public research sector, $S_{1}$ family of garlic by self-pollinating a single plant. In this family, we observed segregation for morphological traits and molecular markers, revealing that the parental plant was heterozygous for loci conditioning these traits. Our results revealed that, on average, one SNP occurs every 210 bases in garlic (Table 1). SNPs have been reported to occur in every 189 bases in Hordeum vulgare L. (Kanazin et al., 2002), 130 bases of Beta vulgaris L. (Schneider et al., 2001), and $1.9 \mathrm{~kb}$ of the human genome (The International SNP Map Working Group, 2001). If this SNP frequency is extrapolated to the entire garlic genome at 15,900 megabasepairs per 1C (Ori et al., 1998), there could be as many as $7.5 \times 10^{7} \mathrm{SNPs}$ in garlic. The prevalence of SNP transitions (63\%) over transversions (37\%) in our study agrees with the results of Schneider et al. (2001) in Beta vulgaris and Kuhl et al. (2004) in Allium cepa. 
Table 2. Names, dominance, and goodness-of-fit to expected ratios for markers segregating in $\mathrm{S}_{1}$ family of garlic.

\begin{tabular}{|c|c|c|}
\hline$\overline{\text { Locus }^{z}}$ & Segregation & $\chi^{2}$ \\
\hline$\overline{\text { ACAAC24_PA }}$ & Dominant & 3.22 \\
\hline ACAAJ79 & Codominant & $17.74^{* *}$ \\
\hline АСАВР69 & Codominant & $19.83^{* *}$ \\
\hline ACACF11 & Codominant & $20.40^{\text {*** }}$ \\
\hline ACACU91 & Codominant & $54.39^{* *}$ \\
\hline ACACU91_PA & Dominant & 0.93 \\
\hline ACADF77 & Codominant & $43.98^{* *}$ \\
\hline ACADQ29 & Codominant & $9.31^{* *}$ \\
\hline ACADR76_PA & Dominant & $8.33^{* *}$ \\
\hline ACADS09_PA & Dominant & $15.47^{* *}$ \\
\hline ACAEI52 & Codominant & $69.65^{* *}$ \\
\hline ACAEI52_PA & Dominant & 2.07 \\
\hline ACAEL31 & Codominant & $15.62^{* *}$ \\
\hline AOB271 & Codominant & 3.95 \\
\hline ACAGG12 & Codominant & $34.30^{* *}$ \\
\hline ACM91 (SSR) & Codominant & 0.89 \\
\hline AJK295 & Codominant & $98.11^{* *}$ \\
\hline AJK295_PA & Dominant & 3.64 \\
\hline AOB 155 & Codominant & 5.33 \\
\hline AOB155_PA & Dominant & $14.06^{* *}$ \\
\hline ACAHF16_PA & Dominant & $12.21^{* *}$ \\
\hline ACAGT43+ACAIC61_PA & Dominant & $16.11^{\text {*** }}$ \\
\hline ACABC 10 & Codominant & $6.37^{*}$ \\
\hline ACAGV59 & Codominant & $78.48^{\text {** }}$ \\
\hline ACAAL62+ACADZ01 & Codominant & 5.98 \\
\hline API15 & Codominant & $26.84^{* *}$ \\
\hline API18 & Codominant & $6.11^{*}$ \\
\hline API31 & Codominant & $24.38^{* *}$ \\
\hline API47 & Codominant & $17.68^{* *}$ \\
\hline OPD3_1500 (RAPD) & Dominant & 1.07 \\
\hline OPD3_2500 (RAPD) & Dominant & 0.60 \\
\hline Mf & Dominant & $7.68^{* *}$ \\
\hline ACAEI72 & Codominant & $25.93^{* *}$ \\
\hline ACAEI72_PA & Dominant & $10.39^{\text {** }}$ \\
\hline ACABI04_PA & Dominant & $8.49^{* *}$ \\
\hline ACAFV90 & Codominant & $97.20^{* *}$ \\
\hline ACABO23F+R_PA & Dominant & $8.49^{* *}$ \\
\hline ACADS93 & Codominant & $15.43^{* *}$ \\
\hline ACACS33 & Codominant & $14.55^{* *}$ \\
\hline ACAET81_PA & Dominant & $11.60^{\text {** }}$ \\
\hline ACAGW96 & Codominant & 1.06 \\
\hline ACAAB50 & Codominant & $17.51^{* *}$ \\
\hline ACADR76_IND & Dominant & $8.33^{* *}$ \\
\hline API66 & Codominant & $22.39^{* *}$ \\
\hline ACAFP01 & Codominant & $25.04^{* *}$ \\
\hline ACABZ07 & Codominant & $87.94^{* *}$ \\
\hline ACAAR73 & Codominant & $21.39^{* *}$ \\
\hline ACABE16 & Codominant & $44.34^{* *}$ \\
\hline ACAHH57+ACAGD43_PA & Dominant & $9.04^{* *}$ \\
\hline ACADT57_PA & Dominant & $11.86^{* *}$ \\
\hline ACABK14+ACAFS70_PA & Dominant & $10.68^{* *}$ \\
\hline ACAGI52_PA & Dominant & $16.43^{* *}$ \\
\hline ACAFC74+ACAAH76_PA & Dominant & $15.79^{* *}$ \\
\hline
\end{tabular}

${ }^{2}$ Name of the locus was after their respective primers name and corresponds to onion expressed sequences tags (AC prefixes) or simple sequence repeats (ACM91) as described by Kuhl et al. (2004) or previously mapped cDNAs (AOB or API prefixes) as described by King et al. (1998) or randomly amplified polymorphic DNA (OP prefixes); PA indicates segregations of presence vs. absence of amplicons, IND is an insertion-deletion event; $\mathrm{Mf}=$ male fertility.

$* *$ and $*$ show significant deviations from expected ratios at the 0.01 and 0.05 levels, respectively, using chi-square tests.
We observed significant deviations from expected ratios for 42 of 53 markers. The main factor contributing to segregation distortion could be the loss of progeny plants due to linkage with deleterious alleles. Because garlic has been asexually propagated for centuries, it is likely that mutation has produced deleterious alleles that are maintained in the heterozygote state. After sexual reproduction, progeny plants homozygous for these deleterious alleles genes should show reduced vigor or perish (Jenderek, 2004). We also observed that 18 markers segregated as the presence vs. absence of amplicons. Mutations or insertion-deletion events at the priming sites could result in no amplifications from one-fourth of the $S_{1}$ plants. Bhattramakki et al. (2002) reported that insertion-deletion events occur in maize (Zea mays L.) by active transposons and by abnormal meiotic events such as unequal crossing over, replication slippage, or slipped-strand mispairing. Abnormal meiotic division has been reported in garlic (Pooler and Simon 1994). Simon and Jenderek (2003) reported that seedling vigor and survival in garlic increased with progressing seed cycles, implying that increased chromosomal stability and selection against deleterious mutations are benefits of sexual reproduction.

We constructed the first genetic linkage map of garlic, composed of nine linkage groups (Fig. 1). The identification and mapping of more markers will be necessary to fill gaps and ultimately resolve the eight linkage groups of garlic.

The major results of this study are segregation analyses of molecular markers as a foundation for garlic genetics and the identification and mapping of a major locus $(M f)$ affecting male fertility in garlic, which is essential for seed production and crop improvement. The identification of molecular markers more closely linked to the $M f$ locus will eventually permit marker-assisted breeding of male-fertile garlic. These male-fertile populations will also allow for breeding of superior garlic cultivars. There are many problems associated with clonal propagation of garlic, including the identification of garlic plants adapted to specific production areas or regimes, costly isolation and maintenance of virus-free plants, and production of virus-free cloves for planting. Seed propagation of garlic will address these problems by allowing for selection of unique or superior garlic plants, elimination of viruses that are not seed transmitted, and ultimately the production of hybrid cultivars.

\section{Literature Cited}

Augusti, K.T. 1990. Therapeutic and medicinal values of onions and garlic, p. 93-108. In: H.D. Rabinowitch and J.L. Brewster (eds.). vol. III. Onions and allied crops: Biochemistry, food science, and minor crops. CRC Press, Boca Raton, Fla.

Bhattramakki, D., M. Dolan, M. Hanafey, R. Wineland, D. Vaske, J.C. Register, S.V. Tingay, and A. Rafalski. 2002. Insertion-deletion polymorphism in 3' regions of maize genes occur frequently and can be used as highly informative genetic markers. Plant Mol. Biol. 48:539-547.

Block, E., S. Ahmad, M.K. Jain, R.W. Crecely, R. Apitz-Castro, and M.R. Cruz. 1984. (E, Z)-Ajoene, a potent antithrombotic agent from garlic. J. Amer. Chem. Soc. 106:8295-8296.

Clark, A.G. 1990. Inference of haplotypes from PCR-amplified samples of diploid populations. Mol. Biol. Evol. 7:111-122.

Etoh, T. 1983. Germination of seeds obtained from a clone of garlic, Allium sativum L. Proc. Jpn. Acad. 59(Ser. B):83-87.

Etoh, T. 1986. Fertility of the garlic clones collected in Soviet Central Asia. J. Jpn. Soc. Hort. Sci. 55:312-319.

Etoh, T. and C. Hong. 2001. RAPD markers for fertile garlic. Acta Hort. 555:209-212. 

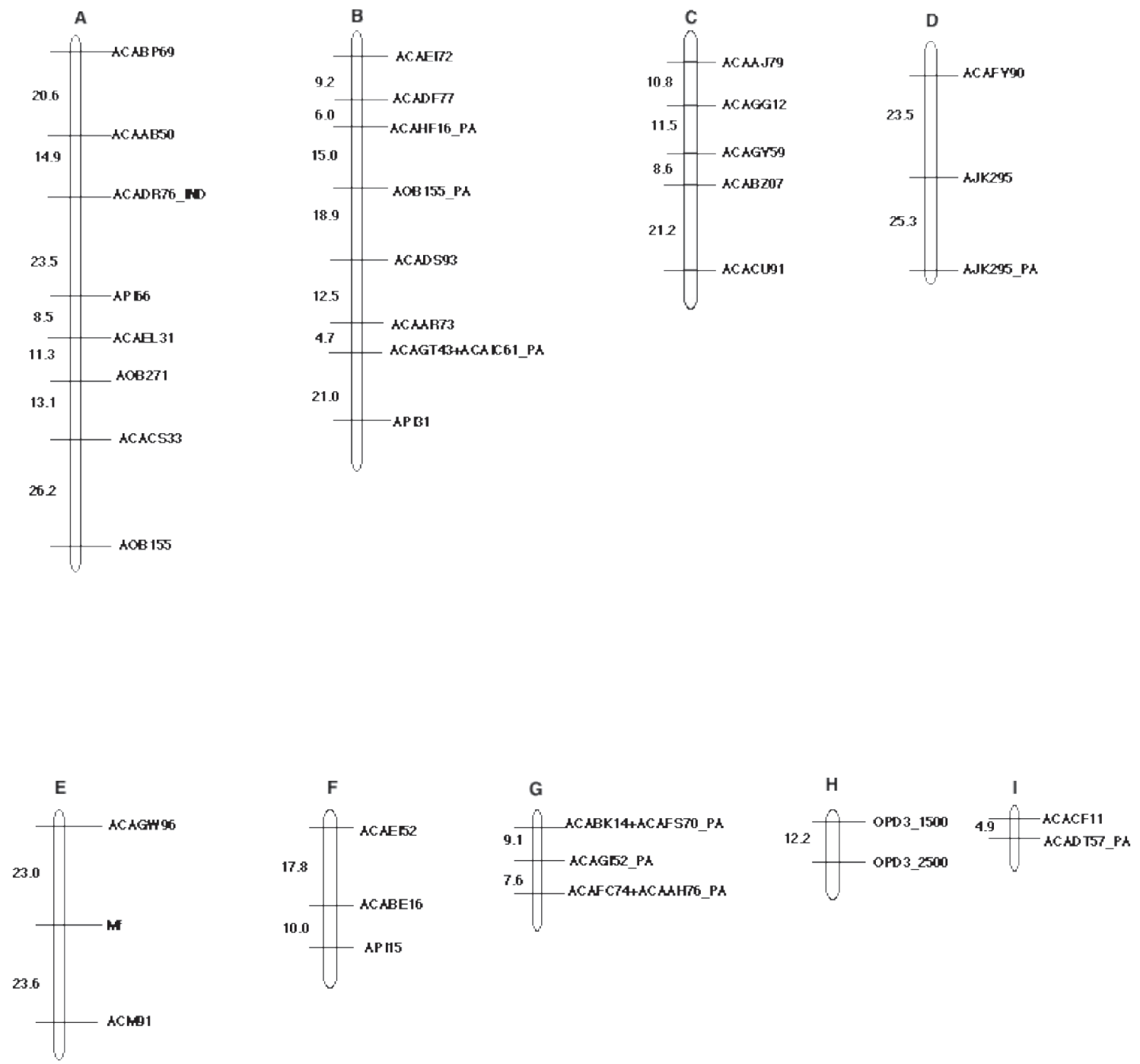

Fig. 1. A molecular linkage map of garlic. Map distances, in cM, are to the left and locus designations (after their respective primer name) are to the right of each group. The indel marker has extension of "IND" and presence/absence of band markers have extensions of "PA." Markers ACAAC24_PA, ACACU91_PA, ACADQ29, ACADR76_PA, ACADS09_PA, ACAEI52_PA, ACABC10, ACAAL62+ACADZ01, API18, API47, ACAEI72_PA, ACABI04_PA, ACABO23F+ ACABO23R_PA, ACAET81_PA, ACAFP01, and ACAHH57+ACAGD43_PA remained unlinked.

Etoh, T. and P.W. Simon. 2002. Diversity, fertility and seed production of garlic, p. 101-117. In: H.D. Rabinowitch and L. Currah (eds.). Allium crop science: Recent advances. CABI, New York.

Fritsch, R.M. and N. Friesen. 2002. Evolution, domestication and taxonomy, p. 5-30. In: H.D. Rabinowitch and L. Currah (eds.). Allium crop science: Recent advances. CABI, New York.

Hu, Z, P. Li, M. Zhou, Z. Zhang, L. Wang, L. Zhu, and Y. Zhu. 2004. Mapping of quantitative loci (QTLs) for rice protein and fat content using doubled haploid lines. Euphytica 135:47-54.

International SNP Map Working Group. 2001. A map of human genome sequence variation containing 1.42 million single nucleotide polymorphisms. Nature 409:928-933.

Ipek, I., A. Ipek, and P.W. Simon. 2003. Comparison of AFLPs, RAPDs, and isozymes for diversity assessment of garlic and detection of putative duplicates in germplasm collections. J. Amer. Soc. Hort. Sci. 128:246-252.

Jenderek. M.M. 1998. Generative reproduction of garlic (Allium sativum L.) (In Polish) [Rozmanazanie generatywne czosnku (Allium sativum L.)]. Zeszyty Naukowe Akademii Rolniczej im. H. Kollataja w Krakowie 57:141-145.

Jenderek, M.M. 2004. Development of $\mathrm{S}_{1}$ families in garlic. Acta Hort. 637:203-206.

Jenderek, M.M. and R.M. Hannan. 2004. Variation in reproductive characteristics and seed production in the USDA garlic germplasm collections. HortScience 39:485-488.

Kanazin, V., H. Talbert, D. See, P. DeCamp, E. Nevo, and T. Blake. 2002. Discovery and assay of a single-nucleotide polymorphism in barley (Hordeum vulgare). Plant Mol. Biol. 48:529-537.

Keusgen, M. 2002. Health and alliums, p. 357-378. In:H.D. Rabinowitch and L. Currah (eds.). Allium crop science: Recent advances. CABI, New York.

Kik, C. 2002. Exploitation of wild relatives for the breeding of cultivated Allium species, p. 81-100. In: H.D. Rabinowitch and L. Currah (eds.). Allium crop science: Recent advances. CABI, New York.

King, J.J., J. Bradeen, O. Bark, J.A. McCallum, and M.J. Havey. 1998. A low-density genetic map of onion reveals a role for tandem duplication in the evolution of an extremely large diploid genome. Theor. Appl. Genet. 96:52-62.

Kosambi, D.D. 1943. The estimation of map distances from recombination values. Ann. Eugenics 12:172-175.

Kuhl, J.C., F. Cheung, Q. Yuan, W. Martin, Y. Zewdie, J. McCallum, A. Catanach, P. Rutherford, K.C. Sink, M. Jenderek, J.P. Prince, C.D. Town, and M.J. Havey. 2004. Aunique set of 11,008 onion expressed sequence tags reveals expressed sequence and genomic differences between the monocot orders Asparagales and Poales. Plant Cell 16:114-125.

Kuhl, J.C., R.E. Hanneman, and M.J. Havey. 2001. Characterization 
and mapping of Rpi1, a late-blight resistance locus from diploid (1EBN) Mexican Solanum pinnatisectum. Mol. Genet. Genomics 265:977-985.

Lampasona, S.G., L. Martinez, and J.L. Burba. 2003. Genetic diversity among selected Argentinean garlic clones (Allium sativum L.) using AFLP (amplified fragment length polymorphism). Euphytica 132:115-119.

Lander, E., P. Green, J. Abrahamson, A. Barlow, M. Daley, S. Lincoln, and L. Newburg. 1987. Mapmaker: An interactive computer package for constructing primary genetic linkage maps of experimental and natural populations. Genomics 1:174-181.

Lee, H., E. Eom, Y. Lim, J. Bang, and D. Lee. 2003. Construction of a garlic BAC library and chromosomal assignment of BAC clones using the FISH technique. Genome 46:514-520.

Lincoln, S.E., M.J. Daly, and E.S. Lander. 1992. Constructing genetic maps with Mapmaker/EXP 3.0. Whitehead Inst. Tech. Rpt. 3rd ed., Cambridge, Mass.

Makheja, A.N. and J.M. Bailey. 1990. Antiplatelet constituents of garlic and onion. Agents Actions 29:360-363.

Mann, L.K. and T.M. Little. 1957. Growing garlic in California. Univ. of Calif. Veg. Crops Ser. 89:1-10.

Ori, D., R.M. Fritsch, and P. Hanelt. 1998. Evolution of genome size in Allium (Alliaceae). Plant Systematics and Evolution 210:57-86.

Pooler, M.R. and P.W. Simon. 1994. True seed production in garlic. Sexual Plant Reproduction 7:282-286.
Sardesai, N., A. Kumar, K.R. Rajyashri, S. Nair, and M. Mohan. 2002. Identification and mapping of an AFLP marker linked to Gm7, a gall midge resistance gene and its conversion to a SCAR marker for its utility in marker aided selection in rice. Theor. Appl. Genet. 105:691-698.

Sawahel, W.A. 2002. Stable genetic transformation of garlic plants using particle bombardment. Cellular Mol. Biol. Lett. 7:49-59.

Schneider, K., B. Weisshaar, D.C. Borchardt, and F. Salamini. 2001. SNP frequency and allelic haplotype structure of Beta vulgaris expressed genes. Mol. Breeding 8:63-74.

Simon, P.W. 2004. The origin and distribution of garlic: How many garlics are there? 1 Nov. 2004. <http://www.ars.usda.gov/Research/ docs.htm?docid $=5232>$

Simon, P.W. and M.M. Jenderek. 2003. Flowering, seed production, and the genesis of garlic breeding. Plant Breeding Rev. 23:211-244.

Thompson, J.D., D.G. Higgins, and T.J. Gibson. 1994. CLUSTAL W: Improving the sensitivity of progressive multiple sequence alignment through sequence weighting, positions-specific gap penalties and weight matrix choice. Nucl. Acid Res. 22:4673-4680.

Volk, G.M., A.D. Henk, and C.M. Richards. 2004. Genetic diversity among U.S. garlic clones as detected using AFLP methods. J. Amer. Soc. Hort. Sci. 129:559-569.

Zhang, D., M. Ayele, H. Tefera, and H.T. Nguyen. 2001. RFLP linkage map of the Ethiopian cereal tef (Eragrostis tef (Zucc) Trotter). Theor. Appl. Genet. 102:957-964. 